\title{
KAROTENOID PADA ALGAE: KAJIAN TENTANG BIOSINTESIS, DISTRIBUSI SERTA FUNGSI KAROTENOID
}

\author{
Windu Merdekawati ${ }^{1 *}$, Ferry F. Karwur ${ }^{2}$, A. B. Susanto ${ }^{1}$ \\ ${ }^{1}$ Program Studi Teknologi Pangan, Fakultas Kedokteran dan Ilmu Kesehatan, Universitas Kristen Satya \\ Wacana, Jl. Kartini No.11A, Salatiga 50711, Jawa Tengah \\ ${ }^{2}$ Program Studi Gizi, Fakultas Kedokteran dan Ilmu Kesehatan, Universitas Kristen Satya Wacana, Jl. Kartini \\ No.11A, Salatiga 50711, Jawa Tengah \\ ${ }^{3}$ Program Studi Ilmu Kelautan, Fakultas Perikanan dan Ilmu Kelautan, Universitas Diponegoro, Jl. Prof. H. \\ Soedharto, S.H, Tembalang, Semarang 50275, Jawa Tengah \\ *Corresponding author: winz.merdekawati18@gmail.com
}

\begin{abstract}
ABSTRAK
Karotenoid terdistribusi pada archaea, bakteri, jamur, tumbuhan, hewan serta algae. Karotenoid dihasilkan dari komponen isopentenyl pyrophosphate (IPP) yang mengalami proses secara bertahap untuk membentuk beragam jenis karotenoid. Terdapat dua kelompok karotenoid yaitu karoten dan xantofil dengan berbagai jenis turunannya. Struktur kimia pada karotenoid algae yaitu allene, acetylene serta acetylated carotenoids. Algae mempunyai karotenoid spesifik yang menarik untuk dipelajari. Setiap kelas algae mempunyai komposisi karotenoid yang berbeda. Untuk memahami tentang karotenoid algae perlu diketahui jalur biosintesisnya serta enzim yang berperan di dalamnya. Karotenoid terdistribusi pada membran tilakoid sesuai dengan fungsinya dalam fotosintesis.
\end{abstract}

Kata kunci: algae, karotenoid, biosintesis, fukoxantin, LHC, fotosintesis.

\section{PENDAHULUAN}

Karotenoid merupakan pigmen yang berwarna kuning hingga merah. Secara struktural, karotenoid merupakan senyawa poliena isoprenoid yang terbentuk dari 8 unit isoprena $\mathrm{C}_{5}$. Terdapat lebih dari 750 jenis karotenoid yang dapat ditemukan di alam. Karotenoid terdistribusi pada tumbuhan darat, algae, bakteri, archaea, jamur serta hewan dengan komposisi yang berbeda pada setiap organisme tersebut. Pemahaman mengenai komposisi karotenoid algae akan lebih mendalam apabila jalur biosintesis karotenoid juga diketahui. Review berikut akan membahas mengenai karotenoid algae mencakup jalur biosintesis, distribusi, serta fungsinya dalam fotosintesis. Pembahasan mengenai biosintesis karotenoid difokuskan pada fukoxantin yang merupakan karotenoid utama pada rumput laut coklat. Biosintesis fukoxantin yang dibahas dalam review ini berupa hipotesis karena masih terdapat beberapa bagian yang belum terpecahkan. Pada akhir review akan dibahas mengenai fungsi karotenoid dalam fotosintesis. 


\section{BIOSINTESIS KAROTENOID}

Biosintesis karotenoid diawali dengan kondensasi kepala-ekor pada 2 molekul $\mathrm{C}_{20}$ geranylgeranyl pyrophosphate (GGPP) menghasilkan fitoen $\mathrm{C}_{40}$ yang dikatalisis oleh phytoene synthase (PYS). Fitoen selanjutnya dimodifikasi secara bertahap menjadi $\zeta$-karoten, neurosporen dan likopen oleh phytoene desaturase (PDS), $\zeta$-caroten desaturase (ZDS) dan carotenoid isomerase (CRTISO), terjadi peningkatan jumlah ikatan rangkap terkonjugasi pada setiap tahapnya. Struktur terminal isopren pada molekul likopen selanjutnya mengalami siklisasi oleh lycopen $\beta$-cyclase (LCYB) dan membentuk $\beta$-karoten. Gen pengkode GGPP, PDS, ZDS, CRTISO dan LCYB terdapat pada semua tumbuhan darat dan algae. Jalur biosintesis karotenoid hingga tahap $\beta$-karoten telah terkonservasi pada organisme tersebut.

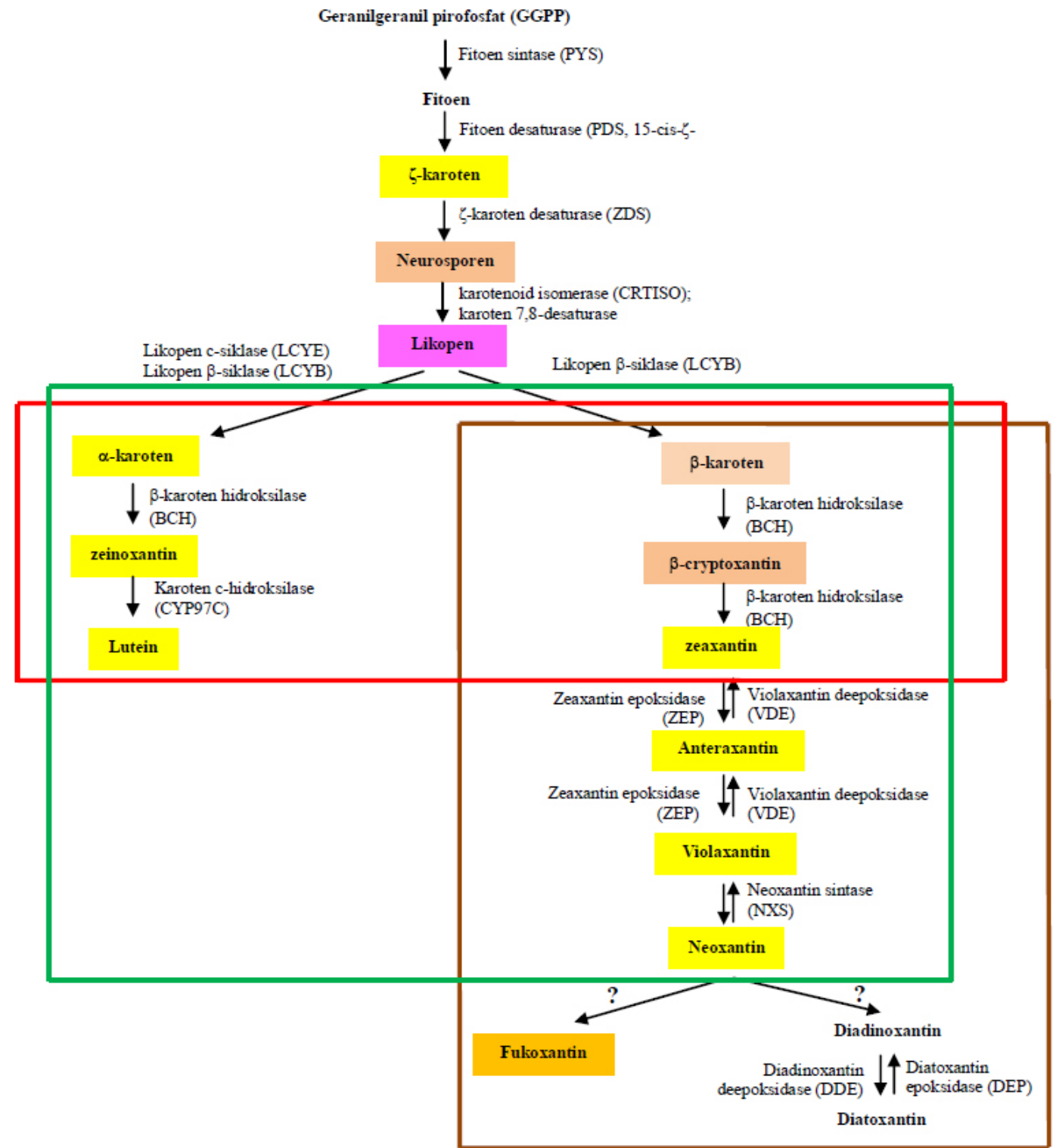

Gambar 1.Jalur biosintesis karotenoid pada algae (warna kotak menunjukkan kenampakan warna karotenoid tersebut; tanda ${ }^{*}$ ) menunjukkan enzim yang tidak teridentifikasi pada rumput laut (Mikami dan Hosokawa, 2013) 
Jalur biosintesis xantofil pada rumput laut merah, hijau dan coklat dapat dilihat pada Gambar 1. Kotak warna merah, hijau dan coklat menunjukkan lingkup jalur biosintesis xantofil pada rumput laut merah, hijau dan coklat. Rumput laut hijau dan tumbuhan darat mempunyai kemiripan komposisi karoten yaitu $\alpha$ dan $\beta$-karoten (Lohr \& Wilhelm, 1998). Pada rumput laut merah, tidak ditemukan jalur biosintesis xantofil setelah zeaxantin sehingga terjadi akumulasi zeaxantin dan lutein (Schubert et al., 2006; Cunningham et al., 2007).

Rumput laut coklat mempunyai xantofil jenis fukoxantin, diadinoxantin serta diatoxantin. Pada rumput laut coklat terdapat siklus xantofil yaitu diadinoxantin cycle yang merupakan siklus reversibel yang mengubah diadinoxantin menjadi diatoxantin maupun sebaliknya. Selain itu juga terdapat violaxantin cycle yaitu siklus reversibel antara zeaxantin, anteraxantin dan violaxantin melalui epoksidasi atau de-epoksidasi (Goss et al., 2010). Siklus tersebut berguna untuk mengatur absorpsi cahaya pada fotosistem ketika berada pada kondisi lingkungan yang ekstrem. Pada algae coklat tidak terdapat $\alpha$-karoten dan turunannya karena lycopene $\alpha$-cyclase (LCYE) gene berasal dari duplikasi gen dalam algal anchestor, sedangkan alga coklat berasal dari endosimbiosis sekunder alga merah sehingga tidak ditemukan LCYE gene dan terdapat gen baru untuk biosintesis xantofil diantaranya fukoxantin, diadinoxantin dan diatoxantin.

Selanjutnya akan dibahas mengenai biosintesis fukoxantin yang merupakan karotenoid utama pada algae coklat. Fukoxantin mempunyai struktur kimia yang unik karena terdapat ikatan alenat dan 5,6-monoepoksida di dalam molekulnya (Gambar 2). Keunikan fukoxantin saat ini banyak mendapatkan perhatian khusus terkait dengan manfaatnya terutama untuk menunjang kesehatan.

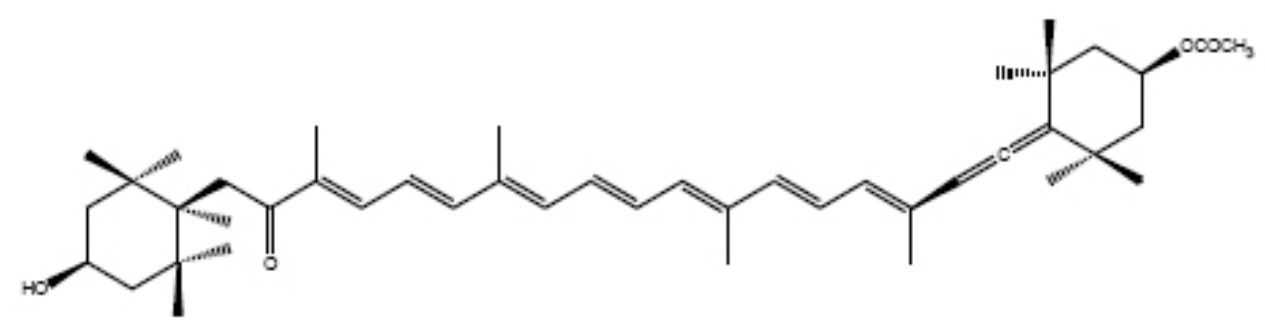

Gambar 2. Struktur kimia fukoxantin

Jalur biosintesis fukoxantin masih belum diketahui secara pasti, berikut beberapa hipotesis terkait hal tersebut. Berdasarkan analisis genom pada 2 spesies diatom yaitu, Thalassiosira pseudonana dan Phaeodactylum tricornutum (Armbrust et al., 2004; Bowler et al., 2008) dihasilkan 2 hipotesis jalur biosintesis fukoxantin yaitu hipotesis diadinoxantin dan hipotesis neoxantin. Pada hipotesis diadinoxantin, $\beta$-karoten diubah menjadi fukoxantin dan diatoxantin melalui diadinoxantin. Hipotesis neoxantin, $\beta$-karoten diubah menjadi fukoxantin dan diadinoxantin dari neoxantin (Gambar 3). Alasan yang mendasari perbedaan hipotesis pada jalur biosintesis fukoxantin ialah: tidak adanya jalur intermediet yang dapat terdeteksi dengan HPLC serta gen pengkode enzim yang terlibat dalam jalur biosintesis fukoxantin belum dapat di-klon (Mikami \& Hosokawa, 2013). Pada konversi neoxantin menjadi fukoxantin terdapat 2 reaksi bertahap yang penting yaitu ketolasi neoxantin dan asetilasi intermediet (Dambek et al., 2012). Hipotesis neoxantin pada rumput laut coklat perlu disertai dengan deteksi biokimia pada intermediet, yang kemungkinan berupa fukoxantinol, serta identifikasi gen pengkode ketolase dan asetilase.

Analisis genom diatom menunjukkan adanya gen untuk enzim yang mirip dengan VDE, yang diistilahkan dengan violaxanthin de-epoxidase-like (VDL), dimana tidak terdapat domain C-terminal, berbeda dengan Glu-rich C-terminus pada VDE. Kenyataannya, gen untuk VDL ditemukan dalam diatom, dinoflagelata dan rumput laut coklat Ectocarpus siliculosus, sehingga Coesel et al (2008) menyatakan adanya keterlibatan VDL pada de-epoksidasi 
xantofil spesifik pada algae coklat, diadinoxantin untuk menghasilkan fukoxantin. Berdasarkan database, E.siliculosus hanya mempunyai satu copy gen ZEP pada genom inti, sama seperti tumbuhan darat lainnya, hal ini menimbulkan pertanyaan apakah terdapat siklus diadinoxantin pada rumput laut coklat. Selain itu juga sulit untuk mendeteksi adanya diadinoxantin dan diatoxantin pada E. siliculosus. Hal tersebut merupakan alasan utama pada gagasan bahwa fukoxantin dihasilkan dari neoxantin (Mikami dan Hosokawa, 2013). Akan tetapi pada hipotesis neoxantin juga masih terdapat pertanyaan yang memerlukan penjelasan yaitu pada rumput laut coklat tidak ditemukan gen pengkode $\beta$-caroten hydroxylase (BCH) dan neoxantin synthase (NXS). Pada genom E. siliculosus tidak ditemukan adanya $c r t R$ atau $c r t Z$. Pada Porphyra juga tidak ditemukan adanya gen $c r t R$ dan $c r t Z$ walaupun studi pada alga merah Cyanidioschyzon merolae menunjukkan adanya gen pengkode $\mathrm{BCH}$ tipe $\mathrm{Cr} t \mathrm{R}$. Berdasarkan analisis tersebut, kemungkinan sintesis zeaxantin pada rumput laut merah dan coklat dikatalisis oleh $\mathrm{BCH}$ yang mungkin mempunyai struktur yang terkait dengan protein CrtR dan CrtZ. Enzim carotene $\varepsilon$-hydroxylase-like (lutein deficient-like, LTL) kemungkinan berfungsi sebagai $\mathrm{BCH}$ dalam diatom, karena ditemukan 2 copy gen tersebut dan tidak terdapat $\alpha$-karoten pada diatom (Coesel et al., 2008; Bertrand, 2010). Akan tetapi, pencarian homologi mengindikasikan bahwa pada genom E. siliculosus tidak ditemukan homologi dengan LTL, hal ini menunjukkan bahwa protein yang mempunyai aktivitas seperti BCH tidak terkait dengan LTL pada rumput laut coklat.

(A)

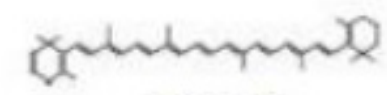

$\beta$-karoten

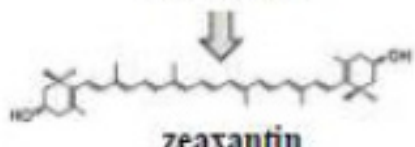

zearantin

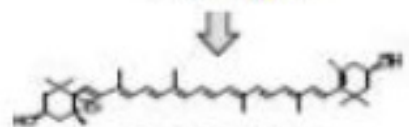

Anteraxantin
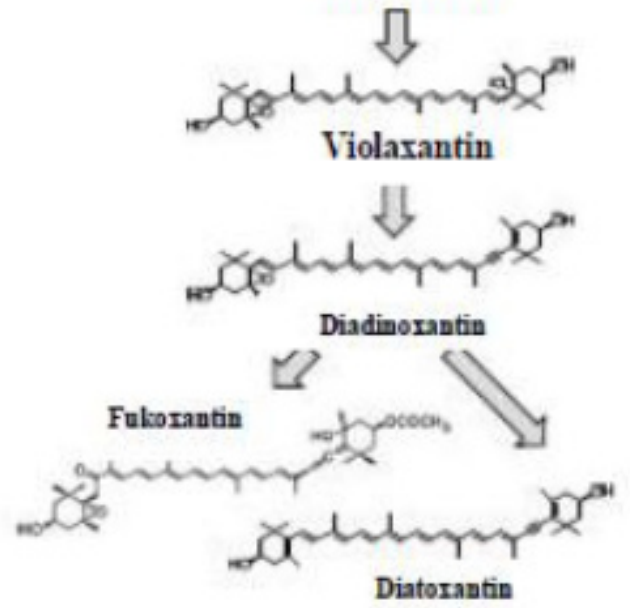

(B)

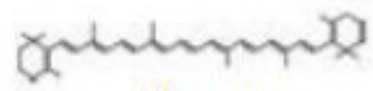

B-karoten

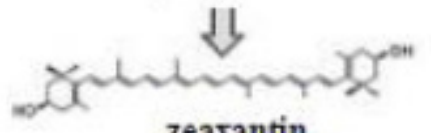

zeaxantin
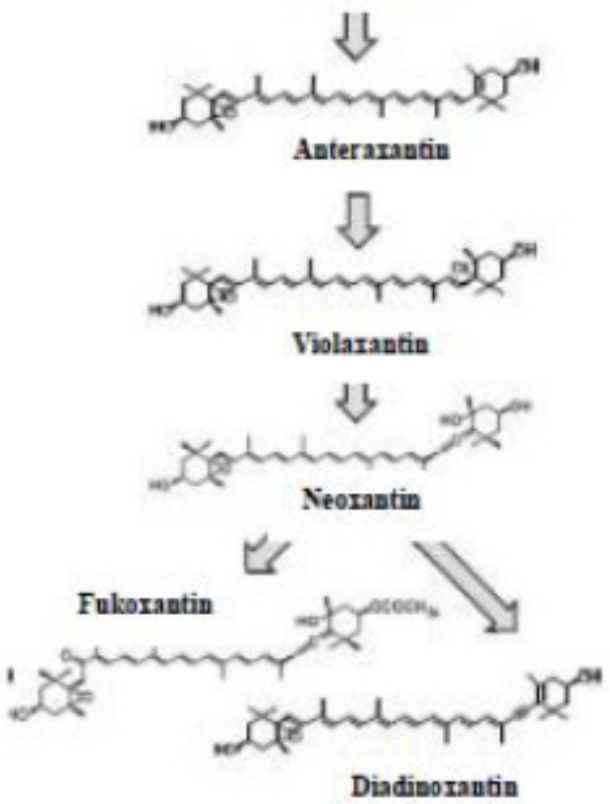

Gambar 3. Jalur biosintesis fukoxantin (A) hipotesis diadinoxantin dan (B) hipotesis neoxantin

Pada rumput laut coklat tidak ditemukan gen pengkode neoxantin synthase (NXS). Kemungkinan rumput laut coklat mempunyai unidentified NXS yang secara struktural tidak terkait dengan NXS. Selain itu NXS dan LCYB 
mempunyai 64\% asam amino yang identik, enzim yang mirip dengan LCYB kemungkinan mengkatalisis produksi neoxantin. Pada genom E. siliculosus ditemukan satu copy gen LCYB, hal ini mengindikasikan bahwa terdapat LCYBlike NXS pada rumput laut coklat. Identifikasi gen NXS tipe baru diperlukan untuk mendukung hipotesis neoxantin. Selain itu juga diperlukan identifikasi ketolase terkait fungsi enzim ini dalam mengkatalisis produksi fukoxantin dari neoxantin. Perlu dikembangkan metode yang mampu untuk melakukan identifikasi gen pengkode enzim tersebut (Mikami dan Hosokawa, 2013).

Tabel 1. Distribusi karotenoid pada algae

\begin{tabular}{|c|c|c|c|c|c|c|c|c|c|c|c|c|c|c|c|c|}
\hline \multirow{2}{*}{$\begin{array}{l}\text { Divisi } \\
\text { Kelas }\end{array}$} & \multicolumn{2}{|c|}{ Karoten } & \multicolumn{10}{|c|}{ Xantofil } & \multirow{2}{*}{ Xantofil lainnya } & \multicolumn{3}{|c|}{ Klorofil } \\
\hline & $\beta$ & $a$ & $\mathrm{Ze}$ & $\mathrm{Vi}$ & $\mathrm{Ne}$ & $\mathrm{Da}$ & $\mathrm{Dd}$ & Fx & $\mathrm{Va}$ & $\mathrm{Lu}$ & Lo & Sx & & $\mathrm{a}$ & $\mathrm{b}$ & $\mathrm{c}$ \\
\hline Cyanophyta & $\mathrm{H}$ & $\mathrm{L}$ & $\mathrm{H}$ & & & & & & & & & & No, L; Ec, H; My & $\mathrm{H}$ & $\mathrm{L}$ & \\
\hline Glaucophyta & $\mathrm{H}$ & & $\mathrm{H}$ & & & & & & & & & & & $\mathrm{H}$ & & \\
\hline \multicolumn{17}{|l|}{ Rhodophyta } \\
\hline Unicellular type & $\mathrm{H}$ & & $\mathrm{H}$ & & & & & & & & & & & $\mathrm{H}$ & & \\
\hline Macrophytic type & $\mathrm{L}$ & $\mathrm{L}$ & $\mathrm{H}$ & $\mathrm{L}$ & & & & $\mathrm{L}$ & & $\mathrm{H}$ & & & & $\mathrm{H}$ & & \\
\hline Cryptophyta & & $\mathrm{H}$ & $\mathrm{L}$ & & & & & & & & & & $\mathrm{Al}, \mathrm{L} ; \mathrm{Cr}, \mathrm{L} ; \mathrm{Mo}, \mathrm{L}$ & $\mathrm{H}$ & & $\mathrm{H}$ \\
\hline \multicolumn{17}{|l|}{ Heterokontophyta } \\
\hline Chrysophyceae & $\mathrm{H}$ & & $\mathrm{L}$ & & & $\mathrm{L}$ & $\mathrm{L}$ & $\mathrm{H}$ & $\mathrm{L}$ & & & & & $\mathrm{H}$ & & $\mathrm{H}$ \\
\hline Raphidophyceae & $\mathrm{H}$ & & $\mathrm{H}$ & $\mathrm{L}$ & & $\mathrm{L}$ & $\mathrm{L}$ & $\mathrm{L}$ & & & & & & $\mathrm{H}$ & & $\mathrm{H}$ \\
\hline Bacillariophyceae & $\mathrm{H}$ & & $\mathrm{L}$ & & & $\mathrm{L}$ & $\mathrm{L}$ & $\mathrm{H}$ & & & & & & $\mathrm{H}$ & & $\mathrm{H}$ \\
\hline Phaeophyceae & $\mathrm{H}$ & & $\mathrm{H}$ & $\mathrm{H}$ & & $\mathrm{L}$ & $\mathrm{L}$ & $\mathrm{H}$ & & & & & & $\mathrm{H}$ & & $\mathrm{H}$ \\
\hline Xanthophyceae & $\mathrm{H}$ & & $\mathrm{L}$ & & & $\mathrm{H}$ & $\mathrm{H}$ & & & & & & Va-FA,L & $\mathrm{H}$ & & $\mathrm{H}$ \\
\hline Eustigmatophyceae & $\mathrm{H}$ & & & $\mathrm{H}$ & & & & & $\mathrm{L}$ & & & & & $\mathrm{H}$ & & \\
\hline Haptophyta & $\mathrm{H}$ & & $\mathrm{L}$ & & & $\mathrm{L}$ & $\mathrm{H}$ & $\mathrm{H}$ & & & & & Fx-FA, L & $\mathrm{H}$ & & $\mathrm{H}$ \\
\hline Dinophyta & $\mathrm{L}$ & & $\mathrm{L}$ & & & $\mathrm{L}$ & $\mathrm{H}$ & $\mathrm{L}$ & & & & & $\mathrm{Pe}, \mathrm{H}$ & $\mathrm{H}$ & & $\mathrm{H}$ \\
\hline Euglenophyta & $\mathrm{H}$ & & $\mathrm{L}$ & & $\mathrm{L}$ & $\mathrm{L}$ & $\mathrm{H}$ & & & & $\mathrm{L}$ & $\mathrm{L}$ & & $\mathrm{H}$ & $\mathrm{H}$ & \\
\hline Chlorarachniophyta & $\mathrm{H}$ & & $\mathrm{L}$ & $\mathrm{L}$ & $\mathrm{L}$ & & & & & $\mathrm{L}$ & $\mathrm{L}$ & & Lo-FA, L & $\mathrm{H}$ & $\mathrm{H}$ & \\
\hline \multicolumn{17}{|l|}{ Chlorophyta } \\
\hline Prasinophyceae & $\mathrm{H}$ & $\mathrm{L}$ & $\mathrm{L}$ & $\mathrm{H}$ & $\mathrm{H}$ & & & & & $\mathrm{L}$ & $\mathrm{L}$ & $\mathrm{H}$ & Pr, L; Lo-FA,L;Sx-FA, H & $\mathrm{H}$ & $\mathrm{H}$ & \\
\hline Chlorophyceae & $\mathrm{H}$ & $\mathrm{H}$ & $\mathrm{L}$ & $\mathrm{H}$ & $\mathrm{H}$ & & & & & $\mathrm{H}$ & $\mathrm{L}$ & $\mathrm{L}$ & Sx-FA, L & $\mathrm{H}$ & $\mathrm{H}$ & \\
\hline Ulvophyceae & $\mathrm{H}$ & $\mathrm{L}$ & $\mathrm{L}$ & $\mathrm{H}$ & $\mathrm{H}$ & & & & & $\mathrm{L}$ & $\mathrm{L}$ & $\mathrm{L}$ & Sx-FA, H & $\mathrm{H}$ & $\mathrm{H}$ & \\
\hline Trebouxiophyceae & $\mathrm{H}$ & & $\mathrm{L}$ & $\mathrm{H}$ & $\mathrm{H}$ & & & & & $\mathrm{H}$ & & & & $\mathrm{H}$ & $\mathrm{H}$ & \\
\hline Charophyceae & $\mathrm{H}$ & & $\mathrm{L}$ & $\mathrm{H}$ & $\mathrm{H}$ & & & & & $\mathrm{H}$ & & & & $\mathrm{H}$ & $\mathrm{H}$ & \\
\hline Land plants & $\mathrm{H}$ & $\mathrm{L}$ & $\mathrm{L}$ & $\mathrm{H}$ & $\mathrm{H}$ & & & & & $\mathrm{H}$ & & & & $\mathrm{H}$ & $\mathrm{H}$ & \\
\hline
\end{tabular}

Keterangan:

$H=$ kadarkarotenoid tinggi; $L=$ kadarkarotenoid rendah; $A l=$ alloxanthin; $C r=$ crocoxanthin; $D a=$ diatoxanthin; $D d=$ diadinoxantin; $E c=$ echinenone; $-F A=$ fatty acid; Fx=fucoxanthin; Lo = loroxantin; Lu=lutein; Mo= monadoxantin; My= myxol glycosides dan oscillol glycoside; Ne= neoxantin; No= nostoxantin; $P e=$ peridinin; $P r=$ prasinoxantin; $S x=$ siphonaxanthin; Va= vaucheriaxanthin, $V i=$ violaxanthin; $Z e=$ zeaxanthin ( ${ }^{*}$ warna merah menunjukkan turunan $\beta$-karoten) (Takaichi, 2011).

\section{DISTRIBUSI KAROTENOID}

Berdasarkan strukturnya karotenoid dibedakan menjadi 2 kelas utama, yaitu karoten dan xantofil. Karoten (misal: $\alpha, \beta, \gamma$-karoten dan likopen) merupakan senyawa hidrokarbon tak jenuh dan tidak mengandung oksigen. Xantofil (misal: lutein, zeaxantin, bixin, rhodoxantin) merupakan turunan karoten yang teroksidasi. Terdapat sekitar 750 jenis karotenoid yang telah ditemukan di alam. Beberapa jenis karotenoid hanya dapat ditemukan pada divisi atau kelas algae tertentu. Jenis karotenoid serta jalur karotenogenesis dapat digunakan sebagai petunjuk dalam kemotaksonomi algae (Liaaen-Jensen, 1990; Jeffrey \& Vesk, 1997). Distribusi karotenoid algae terangkum dalam

\section{Tabel 1.}


Karotenoid mempunyai beberapa struktur kimia yaitu allene, acetylene serta acetylated carotenoids. Allene $(\mathrm{C}=\mathrm{C}=\mathrm{C})$ merupakan struktur unik pada fukoxantin (karotenoid utama pada algae coklat dan diatom); 19'acyloxyfucoxanthin (dalam Haptophyta dan Dinophyta); peridinin (dalam dinoflagellata); serta 9'-cis neoxanthin (dalam algae hijau dan tumbuhan darat) (Dembitsky \& Maoka, 2007). Acetylene $(\mathrm{C} \equiv \mathrm{C})$ juga merupakan struktur unik yang hanya ditemukan pada algae. Struktur ini terdapat dalam karotenoid jenis alloxantin, crocoxantin dan monadoxantin (pada Cryptophyta); diadinoxantin dan diatoxantin (pada Heterokontophyta, Haptophyta, Dinophyta serta Euglenophyta). Kelompok acetylated carotenoids $\left(-\mathrm{O}-\mathrm{CO}-\mathrm{CH}_{3}\right)$ yaitu fukoxantin, peridinin dan dinoxantin ditemukan pada Heterokontophyta, Haptophyta, dan Dinophyta.

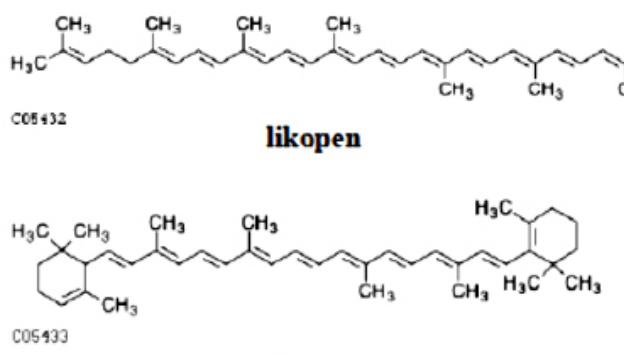

$\alpha$-karoten

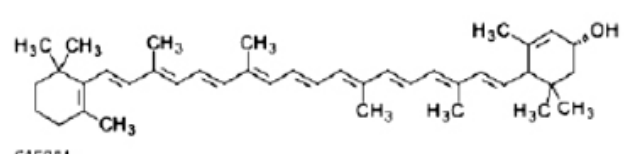

$\alpha$-kriptoxantin

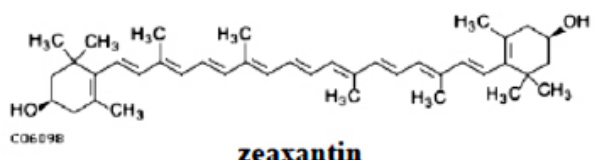

zeaxantin
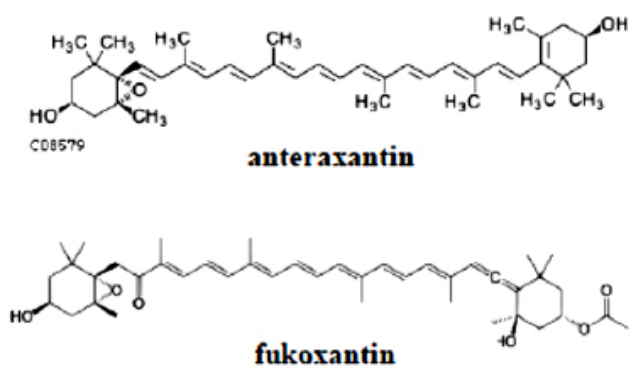

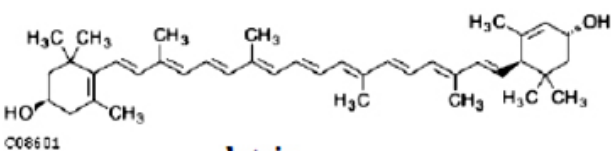
lutein

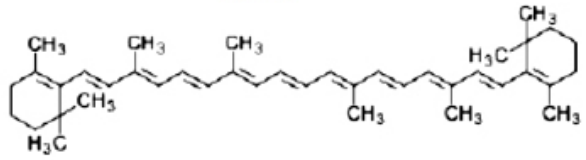

C02094 $\quad \beta$-karoten

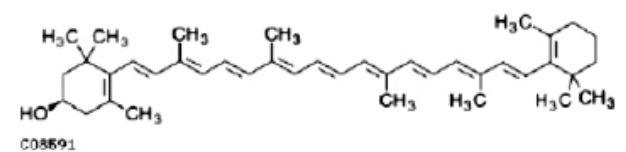

$\beta$-kriptoxantin
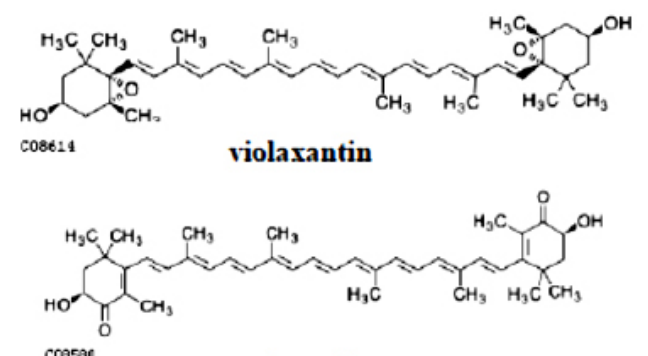

astaxantin

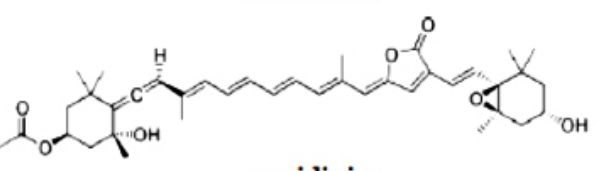

peridinin

Gambar 4. Struktur beberapa jenis karotenoid pada algae

Berdasarkan komposisi karotenoid, Rhodophyta (alga merah) dapat dibedakan menjadi dua kelompok yaitu kelompok uniseluler (hanya mempunyai $\beta$-karoten dan zeaxantin) serta kelompok makrofit. Kelompok makrofit dibagi menjadi dua, yaitu kelompok makrofit yang mempunyai beta-karoten, zeaxantin dan anteraxantin sebagai karotenoid utama dan violaxantin sebagai karotenoid minor, serta kelompok makrofit dengan komposisi karotenoid berupa beta-karoten, zeaxantin, alfa-karoten dan lutein. Cryptophyta juga mengandung $\alpha$-karoten dan turunan acetylenic, crocoxantin serta monadoxantin yang hanya ditemukan dalam divisi ini. Pada Heterokontophyta, Haptophyta dan Dinophyta terdapat $\beta$-karoten dan turunannya serta klorofil c. Divisi tersebut (kecuali Eustigmatophyceae) 
mempunyai diadinoxantin dan diatoxantin. Fukoxantin dan turunannya hanya ditemukan dalam empat kelas Heterokontophyta (Chrysophyceae, Raphidophyceae, Bacillariophyceae, dan Phaeophyceae), Haptophyta serta Dinophyta (Takaichi et al., 1998; Yoshii et al., 2005; Takaichi dan Mochimaru, 2007; Takaichi, 2011). Peridinin dan turunannya hanya ditemukan pada Dinophyta (Takaichi, 2011). Beberapa struktur karotenoid pada algae dapat dilihat pada Gambar 4 berikut ini.

Euglenophyta, Chlorarachniophyta, dan Chlorophyta mempunyai komposisi pigmen yang hampir sama dengan tumbuhan darat, yaitu $\beta$-karoten, violaxantin, 9'-cis neoxantin dan lutein serta klorofil $a$ dan $b$ (Takaichi dan Mimuro, 1998). Beberapa kelas mempunyai karotenoid tambahan yaitu loroxantin, siphonaxantin dan prasinoxantin yang merupakan turunan lutein (Takaichi, 2011).

\section{FUNGSI KAROTENOID}

Klorofil dan karotenoid berikatan dengan peptida, membentuk pigmen-protein kompleks pada membran tilakoid. 5 jenis pigmen protein kompleks pada algae telah diisolasi serta dianalisis komposisi pigmennya (Durnrof, 2003; Macpherson \& Hiller, 2003; Neilson \& Durnford, 2010). Pada fotosintesis, karotenoid mempunyai peranan penting yaitu sebagai pigmen aksesoris pemanen cahaya serta sebagai triplet quencher untuk melindungi komponen fotosintesis dari kerusakan fotooksidatif (Krinsky, 1968; Goodwin, 1976; Cogdell, 1987). Mekanisme fotoproteksi karotenoid meliputi quenching chlorophyll triplet state sehingga mencegah pembentukan oksigen singlet yang dapat mengoksidasi klorofil. Selain itu karotenoid juga mampu mencegah pembentukan oksigen singlet secara langsung. Karotenoid dalam LHC berfungsi untuk menyerap energi pada panjang gelombang yang tidak efisien diserap oleh klorofil. Energi diserap oleh karotenoid dan disalurkan ke klorofil hingga akhirnya sampai pada pusat reaksi. Efisiensi transfer energi dari tahap singlet excited karotenoid ke tahap singlet excited klorofil pada LHC tergantung pada struktur dan eksitasi energi karotenoid serta jarak dan posisinya terhadap klorofil (Bacon Ke, 2001). Singlet state karotenoid mempunyai energi lebih tinggi sedangkan triplet state karotenoid mempunyai energi yang lebih rendah dibandingkan tahapan energi pada klorofil, kondisi tersebut mendukung peran karotenoid sebagai fotoprotektor dan pigmen aksesoris pemanen cahaya (Cogdell, 1987).

Beta-karoten terdapat pada kompleks reaction center (RC) dan light-harvesting complex (LHC) fotosistem I (PSI) serta pada RC dan inti LHC fotosistem II (PS II). Zeaxantin yang terdapat dalam LHC PSI pada beberapa algae merah. Pada bagian periferal LHC PS II, terikat berbagai jenis karotenoid sesuai dengan kelas algae. Karotenoid utama yang ditemukan ialah alloxantin (Cryptophyta); fukoxantin (Chrysophyceae, Raphidophyceae, Bacillariophyceae, Phaeophyceae, serta Haptophyceae); diadinoxantin dan vaucheriaxantin (Xantophyceae); violaxantin dan vaucheriaxantin (Eustigmatophyceae); peridinin (Dinophyta); diadinoxantin (Euglenophyta); siphonaxantin (Chlorophyceae dan Ulvophyceae), serta lutein, violaxantin dan 9'-cis neoxantin (tumbuhan darat) (Durnrof, 2003; Macpherson \& Hiller, 2003; Neilson \& Durnford, 2010). Beta-karoten pada setiap RC mempunyai fungsi proteksi, dan karotenoid pada sisi periferal LHC PSII berfungsi sebagai pemanen cahaya.

Gugus keto pada atom C-8 fukoxantin (Englert et al., 1990), siphonaxantin (Egeland et al., 1997; Yoshii et al., 2002) dan prasinoxantin (Egeland dan Liaaen-Jensen, 1995) hanya ditemukan pada algae. Berdasarkan hasil analisis femtosecond time-resolved fluorescence spectroscopy karotenoid murni dalam pelarut organik dan LHC pada pelarut, kelompok keto-karotenoid dan peridinin mempunyai kemampuan yang efisien dalam transfer energi dari tahap $S_{1}$

(bukan tahap $\mathrm{S}_{2}$ ) karotenoid ke klorofil. Dibandingkan dengan struktur karotenoid lainnya, gugus keto mempunyai efisiensi tinggi (Mimuro et al., 1992; Akimoto et al., 2008). Keto-karotenoid mungkin berperan dalam memanen 
cahaya.

Siklus xantofil (yang juga dikenal sebagai siklus violaxantin) merupakan siklus interkonversi violaxantin, anteraxantin dan zeaxantin pada algae dan tumbuhan darat (Yamamoto et al., 1999). Zep mengkatalisis konversi zeaxantin menjadi violaxantin melalui anteraxantin selama biosintesis. Violaxantin terdapat pada bagian periferal LHC PSII. Pada kondisi cahaya dengan intensitas tinggi, Vde diaktivasi dan mengkatalisis de-epoksidasi violaxantin menjadi zeaxantin melalui anteraxantin. Zeaxantin digunakan untuk mendisipasi energi berlebih dari klorofil yang tereksitasi. Kondisi serupa juga terjadi dalam siklus diadinoxantin pada Heterokontophyta, Haptophyta dan Dinophyta, akan tetapi enzim yang berperan dalam siklus ini belum diketahui (Yamamoto et al., 1999; Goss \& Jacob, 2010). Siklus xantofil memegang peranan penting dalam melindungi komponen fotosintetik dari kerusakan akibat fotooksidasi (Demmig-Adams dan Adams, 1992).

\section{PENUTUP}

Jalur biosintesis karotenoid khususnya pada algae masih perlu untuk dipelajari lebih lanjut karena merupakan pengetahuan dasar yang bermanfaat untuk eksplorasi selanjutnya. Berbagai jenis karotenoid yang terdapat di alam khususnya pada algae serta beragam manfaatnya untuk kehidupan merupakan potensi yang perlu untuk dikembangkan. Perlu penguatan kemampuan pemahaman dan penguasaan ilmu serta teknologi yang mendalam, baik pada lingkup hulu maupun hilir. Ketersediaan sumber daya alam didukung sumber daya manusia yang unggul, kerja sama beberapa stakeholder serta regulasi yang tepat sasaran bukan tidak mungkin komponen-komponen 'kecil' ini dapat menyumbangkan manfaat dengan implikasi yang luas.

\section{UCAPAN TERIMAKASIH}

Penulis mengucapkan terimakasih kepada Beasiswa Unggulan atas dukungan beasiswa pendidikan untuk studi pascasarjana dan kepada Dr. Shinichi Takaichi atas komunikasi singkat dan referensi mengenai biosintesis pigmen algae merah.

\section{DAFTAR PUSTAKA}

Akimoto, S., Yokono, M., Higuchi, M., Tomo, T., Takaichi, S., Murakami, A., Mimuro, M. 2008. Solvent effects on excitation relaxation dynamics of a keto-carotenoid, siphonaxanthin. Photochem. Photobiol. Sci., 7: 12061209.

Armbrust, E.V., Berges, J.A., Bowler, C., Green, B.R., Martinez, D., Putnam, N.H. Zhou, S., Allen, A.E., Apt, K.E., Bechner, M.2004. The genome of the diatom Thalassiosira pseudonana: ecology, evolution, and metabolism. Science, 306: 79-86.

Bakon Ke. 2001. Photosynthesis: Photobiochemistry and Photobiophysics. Kluwer Academics Publisher, Netherland.

Bertrand, M. 2010. Carotenoid biosynthesis in diatoms. Photosynth. Res, 106: 89-102.

Bowler, C., Allen, A.E., Badger, J.H., Grimwood, J., Jabbari, K., Kuo, A., Maheswari, U., Martens, C., Maumus, F., Otillar, R.P. 2008. The Phaeodactylum genome reveals the evolutionary history of diatom genomes. Nature, 456: 239-244.

Coesel, S., Oborník, M., Varela, J., Falciatore, A., Bowler, C. 2008. Evolutionary origins and functions of the carotenoid 
biosynthesis pathway in marine diatoms. PLoS One 3, e2896.

Cogdell, R.J and H. A. Frank. 1987. Biochim. Biophys. Acta 895:63-79.

Cunningham, F.X., Jr., Lee, H and Gantt, E. 2007. Carotenod biosynthesis in the primitive red alga Cyanidioschyzon merolae. Eukaryot. Cell, 6: 533-545

Dambek, M., Eilers, U., Breitenbach, J., Steiger, S., Büchel, C., and Sandmann, G. 2012. Biosynthesis of fucoxanthin and diadinoxanthin and function of initial pathway genes in Phaeodactylum tricornutum. J. Exp. Bot, 63: 5607-5612.

Dembitsky, V.M and Maoka, T. 2007. Allenic and cumulenic lipids. Prog. Lipid Res, 46: 328-375.

Demmig-Adams, B., Adams, W.W. 1992. Photoprotection and other responses of plants to high light stress. Ann. Rev. Plant Physiol, Plant.Mol.Biol, 43: 599-626.

Durnford, D.G. 2003. Structure and regulation of algal light-harvesting complex genes. In Photosynthesis in Algae; Larkum, A.W.D., Douglas, S.E., Raven, J.A., Eds.; Kluwer: Dordrecht, The Netherlands.

Egeland, E.S., Liaaen-Jensen, S. 1995. Ten minor carotenoids from Prasinophyceae (Chlorophyta). Phytochemistry, 40: 515-520.

Egeland, E.S., Guillard, R.R.L., Liaaen-Jensen, S. 1997. Additional carotenoid prototype representatives and a general chemosystematic evaluation of carotenoids in Prasinophyceae (Chlorophyta). Phytochemistry, 44: $1087-1097$.

Englert, G., Bjørnland, T., Liaaen-Jensen, S. 1990. 1D and 2D NMR study of some allenic carotenoids of the fucoxanthin series. Magn. Reson. Chem, 28: 519-528.

Goodwin, T.W. 1976. In Chemistry and Biochemistry of Plant Pigments 1, (T. W. Goodwin, ed.), Academic Press, New York.

Goss, R and Jakob, T. 2010. Regulation and function of xanthophyll cycle-dependent photoprotection in algae. Photosynth. Res, 106: 103-122.

Jeffrey, S.W and Vesk, M. 1997. Introduction to marine phytoplankton and their pigment signatures. In Phytoplankton Pigments in Oceanography: Guidelines to Modern Methods; Jeffrey, S.W., Mantoura, R.F.C., Wright, S.W., Eds.; UNESCO Publishing: Paris, France, pp: 37-84.

Krinsky, N.I. 1968. In Photophysiology III, (A. C. Giese, ed.), Academic Press, New York.

Liaaen-Jensen, S. 1990. Marine carotenoids. New J. Chem, 14: 747-759.

Lohr, M. and Wilhelm, C. 1999. Algae displaying the diadinoxanthin cycle also possess the violaxanthin cycle. Proc. Natl. Acad. Sci. USA , 96: 8784-8789.

Macpherson, A.N., Hiller, R.G.2003. Light-harvesting systems in chlorophyll c-containing algae. In Light-Harvesting Antennas in Photosynthesis; Green, B.R., Parson, W.W., Eds.; Kluwer: Dordrecht, The Netherlands, pp. 323-352.

Mikami, K and Hosokawa, M. 2013. Biosynthetic Pathway and Health Benefits of Fucoxanthin, an Algae-Specific Xantophyll in Brown Seaweeds. Int. J. Mol. Sci. 14: 13763-13781.

Mimuro, M., Nagashima, U., Takaichi, S., Nishimura, Y., Yamazaki, I., Katoh, T. 1992. Molecular structure and optical properties of carotenoids for the in vivo energy transfer function in the algal photosynthetic pigment 
system. Biochim. Biphys. Acta, 1098: 271-274.

Neilson, J.A.D., Durnford, D.G. 2010. Structural and functional diversification of the light-harvesting complexes in photosynthetic eukaryotes. Photosynth. Res, 106: 57-71.

Schubert, N., García-Mendoza, E and Pacheco-Ruiz, I. 2006. Carotenoid composition of marine red algae. J. Phycol, 42: 1208-1216.

Takaichi, S and Mimuro, M. 1998. Distribution and geometric isomerism of neoxanthin in oxygenic phototrophs: 9-cis, a sole molecular form. Plant Cell Physiol, 39: 968-977.

Takaichi, S., dan Mochimaru, M. 2007. Carotenoids and carotenogenesis in cyanobacteria: Unique ketocarotenoids and carotenoid glycosides. Cell. Mol. Life Sci, 64: 2607-2619.

Takaichi, S. 2011. Carotenoids in Algae: Distributions, Biosynthesis and Function. Mar. Drugs, 9: 1101-1118.

Takaichi, S. 2011. Nippon Medical School, Kawasaki, Japan. Unpublished works.

Yamamoto, H.Y., Bugos, R.C., Hieber, A.D. 1999. Biochemistry and molecular biology of the xanthophyll cycle. In The Phytochemistry of Carotenoids; Frank, H.A., Young, A.J., Britton, G., Cogdell, R.J., Eds.; Kluwer: Dordrecht, The Netherlands, pp: 293-303.

Yoshii, Y., Takaichi, S., Maoka, T., Suda, S., Sekiguchi, H., Nakayama, T., Inouye, I. 2002. Variation of siphonaxanthin series among the genus Nephroselmis (Prasinophyceae, Chlorophyta), including a novel primary methoxy carotenoid. J. Phycol, 41: 827-834. 